\title{
Studi Deskriptif Perilaku Dosen Perguruan Tinggi Islam DIY Dalam Membayar Zakat
}

\author{
Oleh: Uzaifah*
}

\begin{abstract}
The various kinds of muzakkis behavior and the differences opinions of the "Ulama" (Islamic religion head) in order of delivering "Zakah" are emerging a curiosity of the Islamic high institution's lecture in Yogyakarta in order of paying "Zakah". Descriptive analysis was used in arranging this research. The questionnaire used by the writer in collecting data which applied accidental sampling method. The lecture characteristic in this research are men (69\%), aged between $30-40$ years old (48\%), master degree in educational level (Strata II) (70\%). The analysis result shown that "Zakah" of wealth calculates 2,5\% from the whole wealth which is "nisab", "Zakah" of income and profession calculates 2,5\% from the gross salary, "zakah" of the commerce wealth calculates 2,5\% from the whole profit gets, "Zakah" pay in money, it was delivered individually, "Zakah" of wealth and commerce wealth pay annually in the around "Ramadhan", "Zakah" of incone and profession are pay after received the salary, and it paid throught institution. The muzakkis behavior which was mentioned are not be in contradiction with the Islamic laws except it concerning with the way of the calculation of the "Zakah" of a commerce wealth which suppose calculating based on the merging of the whole wealth assets. While, for the others behaviors, the Islamic laws gives the "muzakki" freedom to determining his/her "Zakah" payment behavior of course based on the Islamic laws rules and limitations which available.
\end{abstract}

Keywords: perilaku, zakat, muzakki

* Penulis adalah mahasiswa MSI UII Konsentrasi Ekonomi Islam angkatan TA 2007/2008. 
Uzaifah: Studi Deskriptif Perilaku ...

\section{Pendahuluan}

Menegakkan sistem zakat merupakan salah satu kewajiban utama pemerintah karena pemerintah memikul tanggungjawab untuk memelihara semua fakir miskin dan orang-orang yang lemah fisik dan ekonominya sesuai dengan yang terdapat dalam UUD 1945 pasal 34 ayat (1). Peran pemerintah dalam menegakan sistem zakat dapat diaplikasikan dengan membuat sebuah Badan Amil Zakat (BAZ).

Dibentuknya sebuah Badan Amil Zakat di Indonesia ini ternyata belum menjawab masalah pengentasan kemiskinan. Salah satu dampaknya adalah ketidakpuasan muzakki dalam menggunakan jasa BAZ sebagai sarana dalam menyalurkan kewajiban zakatnya sehingga menimbulkan sebuah alternatif perilaku dalam penyaluran zakat yaitu penyaluran zakat yang dilakukan secara individu dimana muzakki akan mencari mustahik secara individu pula. Ulama-ulama pun mempunyai pendapat yang berbeda-beda mengenai perilaku membayarkan zakat.

Bukan hanya perilaku dalam memilih cara membayarkan zakat, apakah dibayarkan melalui sebuah amil zakat ataukan disalurkan secara individu, akan tetapi ada beberapa perilaku muzakki dalam menyalurkan zakatnya baik dilihat dari beberapa segi antara lain waktu, cara dan tempat penyaluran zakat sampai cara perhitungan harta zakat.

Melihat latar belakang masalah yang sudah dikemukakan di atas, maka pokok masalah yang akan dibahas dalam penelitian ini adalah :

A. Bagaimana perilaku dosen Perguruan Tinggi Islam di Yogyakarta dalam melakukan pembayaran zakat?

B. Bagaimana pandangan syariah Islam terhadap perilaku dosen Perguruan Tinggi Islam di Yogyakarta dalam melakukan pembayaran zakat?

Pada penelitian ini penulis hanya memfokuskan penelitian pada Perguruan Tinggi Islam yang ada di Yogyakarta yaitu UII, UIN Suka, UAD, UCY. UMY tidak diikutkan dalam populasi dikarenakan latar belakang UMY dan UAD sama yaitu berbasis Muhammadiyah sehingga apabila diambil salah satu dari dua Perguruan Tinggi Islam tersebut dianggap sudah cukup mewakili populasi penelitian dan juga sebagai upaya efisiensi waktu dan biaya.

Penulis akan menentukan popolasi hanya pada dosen yang sudah wajib zakat. Hal tersebut dapat dipastikan melalui data yang didapatkan dari Lembaga Zakat maupun bagian kepegawaian atau bagian yang berwenang mengeluarkan data tersebut apabila memang tidak didapati sebuah Lembaga Zakat pada Perguruan Tinggi tersebut.

\section{Tinjauan Umum Zakat}

Ditinjau dari segi bahasa, kata zakat merupakan kata dasar dari zaka yang 
berarti berkah, tumbuh, bersih dan baik. Zakat dari segi istilah fikih berarti "Sejumlah harta tertentu yang diwajibkan Allah diserahkan kepada orang-orang yang berhak" disamping berarti "Mengeluarkan jumlah tertentu itu sendiri".

Adapun sifat kekayaan yang wajib zakat dan syarat-syaratnya adalah : milik sempurna, harta tersebut bisa berkembang, cukup nisabnya, jumlahnya lebih dari kebutuhan biasa, bebas dari hutang, sudah cukup haul (waktu). ${ }^{2}$

Terdapat beberapa jenis kekayaan yang disebutkan dan diperingatkan AlQuran untuk dikeluarkan zakatnya sebagai hak Allah selain zakat fitrah dan zakat Maal, yaitu: ${ }^{3}$ Emas dan Perak, Tanaman dan Buah-buahan, Usaha, dan Barang Tambang yang Dikeluarkan dari Perut Bumi.

Ada jenis harta lainnya yang menurut ijtihad sebagian ulama wajib pula dizakatkan, antara lain zakat atas binatang ternak, zakat atas emas dan perak, zakat atas kekayaan dagang, zakat pertanian (tumbuhan dan buah-buahan), zakat madu dan produksi hewani, zakat barang tambang dan hasil laut, zakat atas investasi pabrik gedung dan lain-lain, zakat atas pencarian dan profesi, zakat atas saham dan obligasi, dan zakat fitrah.

\section{Perilaku dalam Membayarkan Zakat}

Perilaku pembayar zakat adalah cara muzakki dalam melakukan kewajiban atas harta zakat yang ada pada dirinya guna menunaikan kewajiban sebagai seorang muslim.

Pada awal masa Islam, yakni masa Rasulullah saw, dan para sahabat, prinsip-prinsip Islam telah dilaksanakan secara demonstratif, terutama dalam hal zakat yang merupakan rukun Islam ketiga. Citra baik mengenai pengumpulan zakat semasa kehidupan Rasulullah dilakukan dengan cara mengumpulkan zakat perorangan dan membentuk panitia pengumpulan zakat, begitu pula pada masa khalifah Abu Bakar Shiddiq dan Umar bin al-Khatab. Pada zaman khalifah Utsman bin Affan, pengumpulan zakat tidak lagi dipusatkan pada khalifah. Selanjutnya, setelah wafatnya Utsman, Ali bin Abi thalib sebagai khalifah terakhir menolak untuk membedakan status masyarakat dalam pembagian harta dari batul maal. Kemudian setelah masa Khulafaur Rasyidin berakhir, sejarah perkembangan zakat berlanjut pada pemerintahan khalifah Muawiyah. Pada masa ini dengan sistem pemerintahan yang lebih baik telah diterapkan pemungutan zakat dari penghasilan, seperti gaji dan pemberian hadiah. Pada masa khalifah Umar bin Abdul Aziz telah dipungut zakat penghasilan

Berikut disebutkan beberapa perilaku muzakki di Indonesia dalam membayarkan zakatnya yang didasarkan pada :

1 Yusuf Qardawi (2006), Fiqhuz-zakat. Salman Harun, Didin Hafiduddin, Hasanuddin (terj.), Hukum Zakat. (Jakarta: PT. Pustaka Litera AntarNusa), hal. 34.

${ }^{2}$ Ibid, hal. 125-166.

${ }^{3}$ Ibid, hal. 122-123. 
Uzaifah: Studi Deskriptif Perilaku ...

A. Cara Menghitung Zakat, yaitu Zakat Harta ( Uang, Emas, dan Perak ) dibayarkan 2, $5 \%$ setelah mencapai nisab atau 2, $5 \%$ setelah sempurna dimiliki selama satu tahun berapapun banyaknya jumlah harta. Zakat Pencarian dan Profesi dibayarkan 2, 5 \% pendapatan bersih atau 2, $5 \%$ pendapatan kotor. Zakat Kekayaan Dagang dibayarkan 2, 5 \% keuntungan atau 2, $5 \%$ modal.

B. Bentuk dari Zakat yang Disalurkan bisa berupa barang dan bisa juga berupa uang.

C. Media Penyaluran Zakat bisa melalui Masjid, Yayasan Sosial, Alim Ulama, Melalui Amil Zakat, atau Langsung disalurkan secara individu.

D. Waktu Pembayaran Zakat, yaitu Zakat Harta ( Uang, Emas, dan Perak) dan Zakat Kekayaan Dagang dibayarkan Setahun sekali sekitar bulan Ramadhan atau Setahun sekali di luar bulan Ramadhan. Untuk Zakat Pencarian dan Profesi dibayarkan Setiap mendapat hasil profesi atau Setahun sekali.

E Jalur Pembayaran Zakat bisa melalui institusi tempat muzakki bekerja ataupun tidak melalui institusi tempat muzakki bekerja.

Untuk Cara perhitungan harta zakt untuk zakat harta tidak ada perdebatan pada keempat mazhab karena perhitungan zakat harta adalah jelas setelah mencapai nisab dan sempurna dimiliki selama satu tahun. Untuk zakat pencarian dan profesi perhitungannya tergantung dari apakah harta pencarian dan profesi adalah sebagai modal saja ataukah modal yang dikembangkan. Untuk zakat kekayaan dagang keempat mazhab sepakat bahwa zakat kekayaan dagang diambil dari jumlah seluruh kekayaan dagangan yang dinominalkan dengan uang yang sudah mencapa nisab di akhir tahun.

Zakat dapat disalurkan dalam bentuk barang maupun uang, keempat mazhab sepakat bahwa lebih utama zakat dikeluarkan dalam bentuk uang.

Pembayaran zakat diperbolehkan untuk melakukannya baik setiap mendapatkan penghasilan maupun setelah satu tahun baru dihitung jumlah zakat yang harus dikeluarkan.

Tidak ada perbedaan pendapat dari para ulama mazhab besar dalam pembayaran zakat apakah melalui sistem potong gaji menurut aturan perusahaan atau institusi maupun tidak dipotong gaji oleh perusahaan maupun institusi.

Mengenai media penyaluran zakat akan lebih diperinci pendapat-pendapat yang dikemukakan oleh keempat mazhab

\section{Organisasi Pengelola Zakat}

Organisasi pengelolaan zakat di Indonesia ada dua macam yaitu Badan Amil Zakat dan Lembaga Amil Zakat yang segala ketentuan mengenai dua organisasi di atas sudah ditentukan dalam Undang-Undang Republik Indonesia Nomor 38 tahun 1999 tentang Pengelolaan Zakat. 


\section{Metode Penelitian}

\section{A. Telaah Pustaka}

Penelitian yang dilakukan oleh Cecep Alamsyah mengungkapkan 90\% pedagang yang sudah wajib zakat di pasar Cikurubuk Tasikmalaya mengeluarkan zakat perdagangan setiap tanggal 25 Ramadhan, sedangkan yang mengeluarkan 2,5\% dari modal berjalan sebanyak 25\%. 70\% mendistribusikan hasil zakatnya kepada kerabat dekat dan pegawainya, sedangkan kepada fakir miskin hanya 30\%. Penelitian yang dilakukan oleh Romansyah Harul mengungkapkan bahwa terjadi peningkatan aktifitas BAZ kota Samarinda setelah diberlakukan UUZ meskipun belum optimal, tetapi usaha ke arah itu cukup kuat. Sama dengan penelitian yang dilakukan oleh Romansyah Harul, penelitian yang dilakukan oleh Gilang Yulianti Latifah mengungkapkan bahwa secara garis besar UU no.38 tahun 1999 tentang Pengelolaan Zakat telah diimplementasikan di BAZIS propinsi DIY baik dalam masalah keorganisasian maupun pengumpulan dan penyaluran zakat, infaq, dan shadaqah. BAZIS propinsi DIY sudah mulai menetapan kembali zakat 2,5\% atas gaji pegawai pemerintah atau swata dan cara penerimaan zakat dari Masyarakat. Dari hasil penelitian tersebut juga dapat dilihat bahwa BAZIS sudah dapat lebih dipercaya dalam melakukan pengelolaan zakat. Dari penelitian yang dilakukan oleh Rahmat Sastra Perdana mengungkapkan dalam pendistribusian zakat pada Badan Amil Zakat Tanggerang melakukan pendayagunaan dana zakat berupa zakat produktif. Pengumpulan zakat melalui media masjid masih belum optimal. Hal tersebut seperti yang diungkapkan oleh Rahmaniar dalam tesisnya dimana pengumpulan zakat baik zakat fitrah maupun zakat maal hanya dilaksanakan menjelang Hari Raya Idul Fitri, dimulai pada bulan puasa. Pendistribusian zakat fitrah dan zakat maal yang untuk keperluan Hari Raya dibagikan pada malam menjelang lebaran diantar langsung oleh panitia zakat kepada mereka yang berhak menerimanya sesuai dengan asnaf yang ada di lingkungan masjid masing-masing, kepada muzakki (72,7 \%) sisanya diserahkan kepada RT/RW untuk diserahkan kepada mereka yang berhak menerimanya dan juga mustahik yang datang langsung minta kepada panitia.

\section{B. Populasi dan Sampel Penelitian}

Populasi dalam penelitian ini adalah semua dosen tetap pada PTI di Yogyakarta. Sampel yang akan diteliti adalah dosen tetap pada keempat PTI di Yogyakarta. Metode sampling yang akan digunakan adalah metode Accidental Sampling

Populasi dalam penelitian ini besarnya diketahui sehingga dalam menghitung sampel yang akan diambil untuk penelitian ini penulis menghitungnya dengan 
Uzaifah: Studi Deskriptif Perilaku ...

menggunakan rumus sebagai berikut: ${ }^{4} \mathbf{n}=\left(\mathbf{N}:\left(\mathbf{1}+\mathbf{N e}^{2}\right)\right)$ dimana : n (Jumlah Sample), N (Jumlah Populasi), e (Tingkat kesalahan pengambilan sampel yang bisa diterima).

Dengan diketahuinya jumlah populasi dan distribusinya pada masingmasing PTI DIY dan dengan tingkat kesalahan 10\%, maka jumlah sampel yang akan diambil yaitu 94 orang dan, yaitu : UII 53 orang; UIN 25 orang; UAD 13 orang ; UCY 3 orang.

\section{Sumber Data}

Dalam penelitian ini, data primer yang akan digunakan adalah hasil kuesioner yang akan dibagikan kepada responden sebagai sampel. Sedangkan untuk data sekunder yang digunakan adalah data dari berbagai literatur yang berkaitan dengan penelitian ini.

\section{Metode Pengumpulan Data}

1. Kuesioner

Jenis kuesioner dalam penelitian ini bersifat semi tertutup dengan metode Multiple Choice Single-Response Scale (Check List).

2. Studi Pustaka

Digunakan dalam keseluruhan proses penelitian dengan memanfaatkan berbagai macam pustaka yang relevan dengan masalah yang tengah dicermati. $^{5}$

\section{E. Metode Analisis Data}

Data akan dianalisis menggunakan analisis deskriptif dengan menampilkan hasil dalam prosentase.

\section{Hasil Penelitian dan Pembahasan}

\section{A. Sampel}

Proses pengumpulan data dilakukan dalam satu tahap. Dari 150 eksemplar kuesioneryang dibagikan, yang kembali ke tangan peneliti sebesar 130 (86,67\%). Dari 130 kuesioner yang kembali, hanya 100 kuesioner yang dapat digunakan

${ }^{4}$ Syamsul Hadi (2006), Metodologi Penelitian Kuantitatif untuk Akuntansi dan Keuangan. (Yogyakarta: Ekonisia), hal: 61.

${ }^{5}$ Ibid, hal: 44. 
untuk kepentingan analisis sebab kuesioner tersebut lebih lengkap dari 30 lembar kuesioner yang tidak digunakan.

\section{B. Deskripsi Responden}

\section{Tabel 5.1 : Proporsi Jenis Kelamin Responden}

\begin{tabular}{|c|c|c|}
\hline Jenis Kelamin & Jumlah Sampel & (\%) Persentase \\
\hline Pria & 65 & 69 \\
\hline Wanita & 29 & 31 \\
\hline Total & $\mathbf{9 4}$ & $\mathbf{1 0 0}$ \\
\hline
\end{tabular}

Sumber : Data Primer

Tabel 5.2 : Proporsi Usia Responden

\begin{tabular}{|c|c|c|}
\hline Usia & Jumlah Sampel & (\%) Persentase \\
\hline tahun $30>$ & 5 & 5 \\
\hline tahun $40-30$ & 45 & 48 \\
\hline tahun $40<$ & 44 & 47 \\
\hline Total & $\mathbf{9 4}$ & $\mathbf{1 0 0}$ \\
\hline
\end{tabular}

Sumber : Data Primer

Tabel 5.3 : Proporsi Pendidikan Terakhir Responden

\begin{tabular}{|c|c|c|}
\hline Pendidikan Terakhir & Jumlah Sampel & (\%) Persentase \\
\hline (Strata I (S-1 & 8 & 9 \\
\hline (Strata II (S-2 & 70 & 74 \\
\hline (Strata III (S-3 & 22 & 17 \\
\hline Total & $\mathbf{9 4}$ & $\mathbf{1 0 0}$ \\
\hline
\end{tabular}

Sumber : Data Primer

Tabel 5.4 : Proporsi Golongan Responden

\begin{tabular}{|c|c|c|}
\hline Golongan / Pangkat & Jumlah Sampel & (\%) Persentase \\
\hline III & 89 & 95 \\
\hline IV & 5 & 5 \\
\hline Total & $\mathbf{9 4}$ & $\mathbf{1 0 0}$ \\
\hline
\end{tabular}

Sumber : Data Primer

Tabel 5.5 : Proporsi Lama Kerja

\begin{tabular}{|c|c|c|}
\hline Lama Kerja & Jumlah Sampel & (\%) Persentase \\
\hline thn $10>$ & 50 & 53 \\
\hline thn $20-11$ & 40 & 43 \\
\hline thn $20<$ & 4 & 4 \\
\hline Total & $\mathbf{9 4}$ & $\mathbf{1 0 0}$ \\
\hline
\end{tabular}


Uzaifah: Studi Deskriptif Perilaku ...

Tabel 5.6 : Proporsi Jabatan Struktural

\begin{tabular}{|c|c|c|}
\hline Jabatan Struktural & Jumlah Sampel & (\%) Persentase \\
\hline Dosen & 69 & 73 \\
\hline Pejabat Universitas & 25 & 27 \\
\hline Total & $\mathbf{9 4}$ & $\mathbf{1 0 0}$ \\
\hline
\end{tabular}

Sumber : Data Primer

\section{Perilaku dalam Memilih Waktu Pembayaran Zakat}

Tabel 5.11 : Perilaku Memilih Waktu Pembayaran Zakat Harta PTI Yogyakarta

\begin{tabular}{|l|c|c|}
\hline \multicolumn{1}{|c|}{ Waktu Pembayaran Zakat } & Jumlah Sampel & (\%) Persentase \\
\hline Setahun sekali pada sekitar bulan Ramadhan & 52 & 56 \\
\hline Setahun Sekali di luar Bulan Ramadhan & 5 & 5 \\
\hline Lainnya & 1 & 1 \\
\hline Tidak Memiliki Harta Zakatnya & 36 & 38 \\
\hline Total & $\mathbf{9 4}$ & $\mathbf{1 0 0}$ \\
\hline
\end{tabular}

Sumber : Data Primer

Tabel 5.16 : Perilaku dalam Memilih Waktu Pembayaran Zakat Pencarian dan Profesi PTI Yogyakarta

\begin{tabular}{|l|c|c|}
\hline \multicolumn{1}{|c|}{ Waktu Pembayaran Zakat } & Jumlah Sampel & (\%) Persentase \\
\hline Setiap Mendapat Hasil Profesi & 84 & 89 \\
\hline Setahun Sekali & 9 & 10 \\
\hline Lainnya & 1 & 1 \\
\hline Tidak Memiliki Harta Zakatnya & 0 & 0 \\
\hline Total & $\mathbf{9 4}$ & $\mathbf{1 0 0}$ \\
\hline
\end{tabular}

Sumber: Data Primer

Tabel 5.21 : Perilaku dalam Memilih Waktu Pembayaran Zakat Kekayaan Dagang PTI Yogyakarta

\begin{tabular}{|l|c|c|}
\hline \multicolumn{1}{|c|}{ Waktu Pembayaran Zakat } & Jumlah Sampel & (\%) Persentase \\
\hline Setahun sekali pada sekitar bulan Ramadhan & 8 & 9 \\
\hline Setahun Sekali di luar Bulan Ramadhan & 3 & 1 \\
\hline Lainnya & 1 & 87 \\
\hline Tidak Memiliki Harta Zakatnya & 82 & $\mathbf{1 0 0}$ \\
\hline Total & $\mathbf{9 4}$ & 3 \\
\hline
\end{tabular}

Sumber: Data Primer

Salah satu syarat diwajibkannya zakat harta adalah sempurna dimiliki selama satu tahun. Ini berarti harta tidak wajib dikeluarkan zakatnya kecuali sekalidalam setahun. Makanya setiap habis waktu setahun, harta wajib dizakatkan.

Menurut mazhab Hanafi, sempurnanya nisab tersebut disyaratkan pada akhir tahun saja, pada permulaan tahun untuk pengikat dan pada akhir tahun 
untuk pewajiban zakat. Maka tidaklah menjadi masalah jika ada kekurangan antara keduanya. Seandainya harta itu rusak atau hilang seluruhnya di tengah masa tersebut maka hilanglah haul. Menurut ulama yang tiga, adanya nisab diibaratkan pada semua haul, berdasarkan pada hadist, "Tiada zakat harta sehingga sampai haul", yakni memaksudkan perjalanan haul secara keseluruhan, karena apa yang diibaratkan pada akhir haul, dapat diibaratkan pada pertengahannya. Adapun harta yang dimanfaatkan dari uang (seperti gaji, upah, honorarium, dan bea-bea jasa dan lain-lain), Jumhur berpendapat tentang semuanya itu untuk disyaratkan haul. Abu Hanifah mengatakan bahwa semua haul tersebut dikumpulkan bersama uang yang dimiliki maka dikeluarkan zakatnya, ketika genap haul harta/uang yang sudah dimiliki tersebut, kecuali jika uang-uang dari hasil usaha tersebut (seperti tersebut di atas) akan dijadikan pengganti harta yang berzakat. Sebagian sahabat tidak menyetujui pertentangan tersebut, maka mereka mewajibkan zakat harta dari jasa-jasa tersebut pada waktu mulai memegangnya, tanpa mensyaratkan haul. ${ }^{6}$

\section{Perilaku dalam Memilih Media Pembayaran Zakat}

\section{Tabel 5.26 : Perilaku Memilih Media Penyaluran Zakat PTI Yogyakarta}

\begin{tabular}{|l|c|c|}
\hline \multicolumn{1}{|c|}{ Media Penyaluran Zakat } & Jumlah Sampel & (\%) Persentase \\
\hline Masjid & 10 & 11 \\
\hline Yayasan Sosial & 4 & 4 \\
\hline Alim Ulama & 0 & 0 \\
\hline Amil Zakat & 37 & 39 \\
\hline Individu & 40 & 46 \\
\hline Lainnya $\quad 0$ & 0 \\
\hline \multicolumn{1}{|c|}{ Total } & $\mathbf{9 4}$ & $\mathbf{1 0 0}$ \\
\hline
\end{tabular}

Sumber : Data Primer

Mengenai perilaku muzakki tersebut di atas, terdapat perbedaan pendapat di kalangan para ulama. Berikut adalah pembahasannya: ${ }^{7}$

Menurut mazhab Hanafi, tugas pengurusan harta zahir diserahkan pada penguasa, bukan pada pemiliknya. Adapun harta batin, diserahkan pada pemiliknya. Menurut ulama mazhab Maliki, bahwa zakat itu wajib diserahkan kepada penguasa yang adil untuk kemudian dibagikan, meskipun ia berlaku zalim selain dalam kedua perbuatan itu. Menurut ulama mazhab Syafi i, bahwa bagi pemilik harta diperbolehkan membagikan zakat hartanya secara langsung oleh dirinya sendiri, atas harta batin, yaitu: emas, perak, harta perdagangan dan zakat fitrah. Adapun harta zahir, hasil pertanian, dan barang tambangan, maka terhadap kebolehan membagikan oleh dirinya sendiri. Menurut ulama mazhab Hanbali, bahwa tidak wajib menyerahkan zakat pada penguasa. Akan tetapi diperbolehkan

${ }^{6}$ Yusuf Qardawi (2006), Op. Cit, hal: 271.

${ }^{7}$ Ibid, hal. 745-749. 
Uzaifah: Studi Deskriptif Perilaku ...

bagi penguasa mengambilnya, dan tidak ada perbedaan dalam mazhab.

\section{E. Perilaku dalam Bentuk dari Zakat yang Disalurkan}

\section{Tabel 5.27: Perilaku Bentuk dari Zakat yang Disalurkan}

\begin{tabular}{|c|c|c|}
\hline Bentuk Zakat yang Disalurkan & Jumlah Sampel & (\%) Persentase \\
\hline Barang & 0 & 0 \\
\hline Uang & 94 & 94 \\
\hline Lainnya & 0 & 0 \\
\hline Total & 94 & 100 \\
\hline
\end{tabular}

Sumber : Data Primer

Zakat yang biasanya dikeluarkan dalam bentuk barang adalah barang dagangan. Pada pembahasan ini kita akan menggunakan zakat perdagangan sebagai acuan.

Dalam hal ini terdapat beberapa pendapat, Abu Hanifah dan Syafi i dalam salah satu fatwanya mengatakan bahwa pedagang itu boleh memilih antara mengeluarkan zakat berupa barang atau uang. Ahmad begitu juga Syafi i dalam fatwanya yang lain mengatakan bahwa zakat harus dikeluarkan berupa uang bukan berupa barang, oleh karena nisab barang dagang dihitung berdasarkan harganya. Oleh karena itu zakat yang dikeuarkan adalah berupa uang yang sama sifatnya dengan barang itu sendiri dalam barang-barang wajib zakat lainnya. ${ }^{8}$ Dalam al-Mughni dikatakan, "Kita tidak menerima pendapat bahwa zakat wajib dikeluarkan berupa barang, yang benar adalah berupa uang."

Pendapat yang terakhir inilah yang lebih kuat ditinjau dari segi kepentingan fakir miskin, oleh karena mereka dapat membeli apa yang mereka butuhkan dengan uang tersebut. Sedangkan barang kadang-kadang tidak diperlukannya, lalu dijualnya dengan harga yang rendah. Pendapat itulah seharusnya yang diambil, bila pemerintahlah yang mengumpulkan dan mendistribusikan zakat, karena lebih tepat dan mudah. Pendapat pertama dapat diterima dalam keadaan tertentu merupakan pengecualian, yaitu apabila yang mengeluarkan zakat adalah pedagang itu sendiri dan ia tahu betul bahwa fakir miskin memerlukan barang tersebut.

\section{F. Perilaku dalam Memilih Jalur Pembayaran Zakat}

Tabel 5.32 : Perilaku dalam Memilih Jalur Pembayaran Zakat PTI Yogyakarta

\begin{tabular}{|c|c|c|}
\hline Jalur Pembayaran Zakat & Jumlah Sampel & (\%) Persentase \\
\hline Melalui Institusi & 80 & 85 \\
\hline
\end{tabular}

${ }^{8}$ Sebagaimana yang dikutip Yusuf Qardawi dalam Al-Mughni, jilid 3: 31; arRaudhah, dalam Yusuf Qardawi (2006), Ibid., hal: 321

${ }^{9}$ Ibid, hal: 32 
Uzaifah: Studi Deskriptif Perilaku ...

\begin{tabular}{|c|c|c|}
\hline Non Institusi & 12 & 13 \\
\hline Lainnya & 2 & 2 \\
\hline \multicolumn{1}{|c|}{ Total } & $\mathbf{9 4}$ & $\mathbf{1 0 0}$ \\
\hline
\end{tabular}

Sumber : Data Primer

Seperti halnya diungkapkan dalam pembahasan mengenai pemilihan media penyaluran zakat. Institusi tempat bekerja bisa dianalogikan sebagai pemerintah yang mempunyai kuasa dalam pengumpulan zakat. Jadi mengenai perilaku dalam pemilihan jalur pembayaran zakat apakah melalui institusi tempat bekerja melalu sistem potong gaji ataukah tidak melalui potong gaji merupakan sebuat keputusan individu itu sendiri. Akan tetapi sebagai bagian dari sebuah institusi tertentu yang mempunyai peraturan tertentu di dalamnya, kita sebagai individu yang sadar memasuki institusi tersebut haruslah mengikuti apa yang sudah menjadi aturan di dalamnya. Apabila zakat penghasilan memang diatur untuk dipotong di awal dan pengelolaannya diserahkan kepada institusi tersebut sepenuhnya maka kita wajib mengikutinya.

\section{G. Perilaku Mengenai Cara Penghitungan Zakat}

\section{Tabel 5.37 : Perilaku dalam Cara Perhitungan Zakat Harta PTI Yogyakarta}

\begin{tabular}{|c|c|c|}
\hline Cara Menghitung Zakat & Jumlah Sampel & (\%) Persentase \\
\hline setelah mencapai nisab \% 2,5 & 52 & 56 \\
\hline $\begin{array}{l}\text { setelah dimiliki satu tahun \% 2,5 } \\
\text { berapapun jumlah harta }\end{array}$ & 10 & 11 \\
\hline Lainnya & 2 & 2 \\
\hline Tidak Memiliki Harta Zakatnya & 30 & 31 \\
\hline Total & $\mathbf{9 4}$ & $\mathbf{1 0 0}$ \\
\hline
\end{tabular}

Sumber : Data Primer

Tabel 5.42 : Perilaku Cara Perhitungan Zakat Pencarian dan Profesi PTI Yogyakarta

\begin{tabular}{|c|c|c|}
\hline Cara Menghitung Zakat & Jumlah Sampel & (\%) Persentase \\
\hline pendapatan bersih \% 2,5 & 16 & 17 \\
\hline pendapatan kotor \% 2,5 & 75 & 80 \\
\hline Lainnya & 3 & 3 \\
\hline Tidak Memiliki Harta Zakatnya & 0 & 0 \\
\hline Total & $\mathbf{9 4}$ & $\mathbf{1 0 0}$ \\
\hline
\end{tabular}

Sumber: Data Primer

Tabel 5.47 : Perilaku Cara Perhitungan Zakat Kekayaan Dagang PTI Yogyakarta

\begin{tabular}{|l|c|c|}
\hline \multicolumn{1}{|c|}{ Cara Menghitung Zakat } & Jumlah Sampel & (\%) Persentase \\
\hline keuntungan \% 2,5 & 9 & 10 \\
\hline modal \% 2,5 & 6 & 6 \\
\hline Lainnya & 1 & 1 \\
\hline Tidak Memiliki Harta Zakatnya & 78 & 83 \\
\hline
\end{tabular}


Uzaifah: Studi Deskriptif Perilaku ...

\begin{tabular}{|c|c|c|}
\hline Total & 94 & 100 \\
\hline \multicolumn{2}{|c|}{ Sumber : Data Primer }
\end{tabular}

Ketiga jenis harta zakat di atas mempunyai kesamaan dalam nilai prosentase yang harus dikeluarkan untuk zakat yaitu sebesar 2,5\%. Ada beberapa syarat yang harus terpenuhi untuk menjadikan harta tersebut sebagai harta yang wajib dizakati, yaitu : ${ }^{10}$ Mencapai nisab, dimiliki secara sempurna selama satu tahun, merupakan kelebihan dari kebutuhan-kebutuhan pokok sehari-hari, dan bersih dari ikatan hutang.

Menurut mazhab Hanafi, sempurnanya nisab tersebut disyaratkan pada akhir tahun saja, pada permulaan tahun untuk pengikat dan pada akhir tahun untuk pewajiban zakat. ${ }^{11} \mathrm{Di}$ antara ulama-ulama fikih ada yang menambah ketentuan nisab kekayaan yang berkembang itu dengan lebihnya kekayaan itu dari kebutuhan biasa pemiliknya, misalnya ulama-ulama Hanafi dalam kebanyakan kitab mereka.

Tetapi ada ulama-ulama yang tidak memasukan ketentuan itu dalam kekayaan yang berkembang. Hal itu oleh karena sesuatu yang menjadi kebutuhan biasa, biasanya tidaklah disebut berkembang atau mempunyai potensi untuk berkembang, sebagaimana jelas terlihat dalah hal rumah tinggal, hewan yang ditunggangi, pakaian yang dipakai, senjata perlengkapan, buku-buku koleksi, dan alat-alat kerja. Semuanya itu adalah kebutuhan rutin dan tidak termasuk kekayaan yang berkembang. Menurut mereka kebutuhan merupakan persoalan pribadi yang tidak bisa dijadikan patokan, dan oleh karena itu suatu kelebihan dari kebutuhan tidak bisa diketahui. Dalil yang dikemukakan bagi kelebihan dari kebutuhan itu adalah dapatnya kelebihan itu ditawarkan dan diperjualbelikan, yang dengan itulah pertumbuhan yang dimaksudkan itu terwujud. Tetapi ketentuan tentang pertumbuhan yang menjadi syarat kekayaan wajib zakat sesungguhnya tidaklah memerlukan ketentuan demikian, oleh karena mereka memandang uang adalah sesuatu yang berkembang dengan sendirinya, karena merupakan sesuatu yang diciptakan untuk kepentingan alat tukar dan investasi sekalipun tidak dikembangkan dengan sengaja oleh pemiliknya. Hal itu oleh karena seandainya ketentuan di atas tidak ada, maka orang yang mempunyai kekayaan sampai senisab pun akan mengatakan bahwa hal itu hanya cukup buat makanan, pakaian, tempat tinggal, pengobatan, ataupun kebutuhan-kebutuhan lainnya untuk keluarga dan anak-anaknya, sedangkan seorang yang berkewajiban memberi nafkah keluarganya sedangkan dia kaya, maka ia berarti sudah kena kewajiban zakat, sekalipun ada ulama-ulama yang memandang seorang yang selalu repot dengan kebutuhan rutinnya sama statusnya dengan orang yang tidak mempunyai apa-apa. Yang kita katakan hanyalah "lebih daripada kebutuhan rutin." Yang dimaksud dengan kebutuhan rutin adalah sesuatu yang tidak

${ }^{10}$ Ahmad Azhar Basyir (1997), Hukum Zakat. (Yogyakarta: Lukman Offset), hal: 25 .

${ }^{11}$ Ibid, hal. 271. 
dapat tidak mesti ada untuk ketahanan hidupnya, seperti makanan, pakaian, minuman, perumahan, dan alat-alat yang diperlukan untuk itu seperti bukubuku ilmu pengetahuan dan keterampilan serta alat-alat kerja lainnya. Dan yang terpenting yang dapat kita lihat di sini adalah bahwa kebutuhan rutin manusia itu berubah-ubah dan berkembang sesuai dengan perubaha zaman, situasi, dan kondisi setempat. Kita sebaiknya menyerahkan persoalan itu kepada penilaian para ahli dan ketetapan yang berwenang. Dan yang menjadi tekanan di sini adalah kebtuhan-kebutuhan rutin orang yan terkena kewajiban zakat itu serta kebutuhan rutin orang-orang yang di bawah tanggungannya, seperti istri, anakanak berapapun jumlahnya, orang tua, dan anggota-anggota keluarga yang lain yang harus ditanggungnya; kebutuhan mereka itu berarti juga kebutuhannya. ${ }^{12}$

Pada zama Nabi dan para sahabatnya, yang menilai dan menentukan seseorang itu muzakki atau mustahik, termasuk kebutuhan pokoknya, adalah amil zakat (untuk menjamin obyektivitas). Sedangkan pada masa sekarang mungkin (untuk sementara) perhitungan kebutuhan pokok diserahkan sepenuhnya pada masing-masing muzakki. ${ }^{13}$

Dari pembahasan di atas dapat dilihat bahwa akan lebih baik zakat dikeluarkan dari pendapatan bersih yang didapat dengan alasan agar seluruh kebutuhan pokoknya dapat dipenuhi dengan baik. Akan tetapi apabila khawatir apabila zakat dikeluarkan dari pendapatan bersih pendapatan yang diterima akan digunakan untuk kebutuhan sekunder yang kurang bermanfaat maka diperbolehkan untuk mengeluarkan zakat dari pendapatan kotornya.

Kekayaan yang diinvestasikan seorang pedagang tidak akan terlepas dari salah satu atau lebih dari tiga bentuk berikut : ${ }^{14}$

1. Kekayaan dalam bentuk barang yang dibelinya tetapi belum terjual.

2. Atau dalam bentuk uang yang secara konkrit berada di dalam genggamannya, atau berada di bawah kekuasannya sperti uang yang berada di dalam rekeningnya di bank.

3. Atau dalam bentuk piutang yang berada di tangan relasi-relasinya dan lainlain yang tidak bisa terlakan oleh sebab sifat dagang dan transaksi. Tentu saja piutang itu ada yang tidak bisa diharapkan kembali dan ada pula yang bisa diharapkan kembali. Perlu diingat bahwa seorang pedagang disamping mempunyai pitang pada orang lain juga mempunyai hutang pada orang lain lagi.

Dengan adanya beberapa bentuk di atas maka seorang muslim dalam mengeluarkan zakatnya dapat melihat beberapa pendapat berikut:

Hasan Basri berkata, "Bila bulan seseorang harus membayar zakatnya sudah datang, maka ia menghitung zakatny dari uang yang ada di tangannya,

${ }^{12}$ Ibid, hal. 486.

${ }^{13}$ Didin HAfidhuddin (2000), Tentang Zakat Infak Sedekah. (Jakarta: Gema Insani Press), hal. 27-28.

${ }^{14}$ Ibid, hal. 316. 
barang yang terjual, dan semua piutangnya, kecuali piutang yang belum jelas dan tidak mungkin diharapkan kembali. " Ibrahim Nakha`i berkata, "Serang harus menghitung harga barang dagangannya, bila sudah sampai temponya, maka ia harus mengeluarkan zakatnya bersama dengan uang lain." 15

Dari pendapat-pendapat di atas itu jelas bahwa seorang pedagang Muslim, bila tempo seharusnya ia berzakat sudah sampai, harus menggabungkan seluruh kekayaan: modal, laba, simpanan, dan iutang yang diharapkan bisa kembali, lalu mengosongkan semua dagangannya dan menghitung semua barang ditambah dengan uang yang ada, baik yang digunakan untuk perdagangan maupun yang tidak, ditambah lagi dengan piutang yang diharapkan bisa kembali, kemudian mengeluarkan zakatnya sebesar $2,5 \%$. Sedangkan piutang yang tidak mungkin lagi kembali, lebih kuat adalah pendapat yang mengatakan bahwa piutang itu untuk kemudian dikeuarkan zakatnya untuk satu tahun. Hal itu berdasarkan pilihan kita bahwa uang yang dipakai hanya dikeluarkan zakatnya waktu diterima kembali bila cukup senisab. Sedangkan hutang harus dikeluarkan terlebih dahulu, kemudian baru dikeuarkan zakat dari sisanya. ${ }^{16}$

Berdasarkan pembahasan di atas dapat dilihat bahwa sebenarnya zakat dari kekayaan dagang dihitung setelah terjadi penggabungan seluruh kekayaan baik modal ataupun keuntungan dan lainnya. Sehingga tidak tepat bila mengambil zakat kekayaan dagang hanya dari keuntungan atau hanya dari modalnya saja.

\section{Penutup}

A. Karakteristik dosen pada Perguruan Tinggi Islam di Yogyakarta yaitu : pria (69\%), usia antara 30 - 40 tahun (48\%), pendidikan terakhir Strata II (70\%), pangkat golongan III (95\%), lama kerja di bawah 10 tahun (53\%), dan tidak terikat jabatan struktural (73\%).

B. Berdasarkan perilaku cara perhitungan zakat yang dilakukan:

1. Zakat Harta (emas dan perak) : 55\% muzakki mengambil 2,5\% dari total harta setelah mencapai nisab.

Mengenai perilaku tersebut tidak ada perdebatan oleh ulama-ulama.

2. Zakat Pencarian dan Profesi : 80\% muzakki mengambil 2,5\% dari pendapatan kotornya.

Mengenai perilaku ini, sebagian besar ulama lebih menganjurkan menghitung berdasarkan pendapatan bersih agar muzakki bisa memenuhi dahulu kebutuhan rutin pokoknya. Akan tetapi perhitungan berdasarkan pendapatan kotor diperbolehkan apabila khawatir pendapatan yang diperoleh dipakai untuk sesuatu yang tidak bermanfaat.

3. Zakat Kekayaan Dagang : 10\% muzakki mengeluarkan zakat sebesar

${ }^{15}$ Al-Amwal,426, dalam Yusuf Qardawi (2006), Op.Cit, hal. 316.

16 Yusuf Qardawi (2006), Op.Cit, hal. 316 -317. 
2,5\% dari keuntungan yang diperoleh. Angka tersebut sangatlah kecil karena 83\% dari Dosen PTI di Yogyakarta tidak melakukan kegiatan perdagangan.

Mengenai perilaku ini, syariah sudah mengatur bahwa perhitungan zakat kekayaan dagang adalah dengan dihitung setelah terjadi penggabungan seluruh kekayaan baik modal ataupun keuntungan dan lainnya. Sehingga tidak tepat bila mengambil zakat kekayaan dagang hanya dari keuntungan atau hanya dari modalnya saja.

C. Berdasarkan perilaku dalam bentuk zakat yang disalurkan : 100\% muzakki menyalurkan zakat kekayaannya dalam bentuk uang dan hal tersebut lebih danjurkan oleh sebagian besar ulama.

D. Berdasarkan perilaku dalam memilih media penyaluran zakat : $44 \%$ muzakki memilih menyalurkan zakatnya secara individu.

Perilaku tersebut diperbolehkan dalam syariat terutama melihat negara Indonesia yang bukan negara Islam sehingga tidak ada kewajiban bagi muzakki untuk menyerahkan harta zakatnya terutama harta zahir.

E. Berdasarkan perilaku dalam memilih waktu pembayaran zakat:

1. Zakat Harta (emas dan perak) : 56\% muzakki membayarkan zakat atas kekayaan hartanya setahun sekali pada sekitar bulan Ramadhan. Perilaku ini diperbolehkan oleh syariat karena kesepakatan para ulama tentang syarat dikeluarkannya harta zakat adalah adanya haul baik jatuhnya di luar atau di sekitar bulan Ramadhan.

2. Zakat Pencarian dan Profesi : 80\% muzakki memilih membayarkan zakat kekayaan atas pencarian dan profesi setiap mendapatkan hasil pencarian dan profesi.

Mengenai pemilihan waktu ini tidak ada perdebatan di kalangan ulama.

3. Zakat Kekayaan dagang: 9\% muzakki membayaran zakat atas kekayaan dagangnya setahun sekali pada sekitar bulan Ramadhan. Kecilnya angka tersebut dikarenakan 87\% dari dosen PTI di Yogyakarta tidak melakukan kegiatan perdagangan.

Mengenai perilaku ini syariah memberikan kebebasan karena haul hanya membatasi genapnya satu tahun kepemilikan baik jatuhnya di luar maupun sekitar bulan Ramadhan.

F. Berdasarkan perilaku dalam memilih jalur pembayaran zakat : $85 \%$ muzakki melakukan pembayaran zakat pencarian dan profesi melalui institusi yang menaungi mereka.

Perilaku ini disepakati oleh ulama selama itu merupakan peraturan yang ada dalam sebuah institusi.

Adapun saran-saran yang dapat penulis sampaikan adalah: 
Uzaifah: Studi Deskriptif Perilaku ...

A. Bagi muzakki yang menghitung zakat pendapatan dan profesi berdasarkan pendapatan bersih hendaknya benar-benar memperhatikan kebutuhankebutuhan pokok apa saja yang harus benar-benar terpenuhi untuk ketahanan hidup agar tidak terjadi sesuatu yang berlebihan.

B. Bagi muzakki yang melakukan kegiatan perdagangan hendaknya benarbenar mencari tahu tentang ketentuan zakat dari harta perdagangan agar tidak terjadi kesalahan dalam menentukan perhitungan harta yang wajib dizakati.

C. Apabila ada pihak yang akan melakukan penelitian dengan tema seperti yang penulis angkat, akan lebih baik apabila dalam pengambilan sampel dapat lebih diperbanyak jumlahnya dan bisa dikembangkan teknik analisis data yang digunakan misalnya menggunakan analisis kuantitatif, agar penelitian yang dilakukan dapat lebih memuaskan dalam hal hasil.

\section{DAFTAR PUSTAKA}

Ahmad Azhar Basyir (1997). Hukum Zakat. Yogyakarta: Lukman Offset.

Al-Ba' Iy, Abdul Al-Hamid Mahud (2006). Ekonomi Zakat Sebuah Kajian Moneter dan Keuangan Syariah. Jakarta: Rajawali Press.

Al-Jamal, Ibrahim Muhammad (1986). Fiqhul Mar'ah Al-Muslimah. Anshori Umar Sitanggal (terj.). Fiqih Wanita. Semarang: CV. Asy-Syifa`.

Al-Quran dan Terjemah. Yogyakarta: UII Press.

Didin Hafidhuddin (2000). Tentang Zakat Infak Sedekah. Jakarta: Gema Insani Press.

Hariwijaya dan Bisri M. Djaelani (2006). Teknik Menulis Skripsi dan Thesis. Yogyakarta: Hanggar Kreator.

Heri Sudarsono dan Hendi Yogi Prabowo (2004). Istilah-Istilah Bank dan Lembaga Keuangan Syariah. Yogyakarta: UII Press.

http://www.google.com/2005-04-21/artikel.pengertianperilaku/ SilabusUPI. htm, diakses pada 27 November 2006.

http://www.google.com/2006-03-21/artikel.pengertianperilaku/ kinerjaketerampilan.

mht, diakses pada 19 Desember 2006.

http://www.ucy.co.id/profil UCY.htm, diakses pada 12 Juli 2006.

http://www.uii.ac.id//sejarah.htm., diakses pada 12 Juli 2006.

http://www.uinsuka.co.id//sejarah.htm., diakses pada 12 Juli 2006.

Imam Suprayogo dan Tobroni (2003). Metodologi Penelitian Sosial-Agama.

Bandung: PT Remaja Rosdakarya.

Mughniyah, Muhammad Jawad (2006). al-Fiqh 'ala al-Madzahib al-Khamsah. Masykur, Afif Muhammad, Idrus Al-Kaff (terj.). Fiqih Lima Mazhab. 
Jakarta: Lentera.

Muhammad (2002). Zakat Profesi: Wacana Pemikiran dalam Fikih Kontemporer. Jakarta: Salemba Diniyah.

Muhammad dan Ridwan Mas'ud (2005). Zakat dan Kemiskinan Instrumen Pemberdayaan Ekonomi Umat. Yogyakarta: UII Press.

Pedoman Akademik UAD 2006-2007 (2006). Yogyakarta.

Qardawi, Yusuf (2006). Fiqhuz-zakat. Salman Harun, Didin Hafiduddin, Hasanuddin (terj.). Hukum Zakat. Jakarta: PT. Pustaka Litera AntarNusa.

Sajogyo dan Jiwati Sajogyo (1983). Sosiologi Pedesaan. Yogyakarta: Gajahmada University Press.

Syamsul Hadi (2006). Metodologi Penelitian Kuantitatif untuk Akuntansi dan Keuangan. Yogyakarta: Ekonisia.

UUD 1945 (2004). Surakarta: Pustaka Mandiri.

Yusuf Wibisono (2005). Metode Statistik. Yogyakarta: Gadjah Mada University Press. 